\title{
Editorial
}

\section{Total intravenous anaesthesia}

The concept of balanced anaesthesia is not new. Specific anaesthetic drugs are used to produce specific effects which comprise the anaesthetic state, namely hypnosis, obtundation of autonomic reflexes, and muscular relaxation. No single agent exists which provides all these components with an acceptable margin of safety. Thus we use barbiturates for induction of hypnosis, muscle relaxants to obtain paralysis, narcotics for attenuation of the pressor response, in combination with inhaled agents in an attempt to minimize the toxic effects of larger doses of individual agents given alone.

The intravenous drugs traditionally used to achieve these ends are old friends which have stood the test of time: thiopentone, morphine, meperidine, $d$-tubocurarine and, more recently, fentanyl and pancuronium. The major problem with these drugs is that they exhibit accumulation. That is, as dosages are repeated the length of action increases making it very difficult to carry out procedures of intermediate and long duration without a prolonged recovery period. This effect is more pronounced in the absence of nitrous oxide since larger doses of intravenous agents are required. Recently, however, new drugs have been synthesized with pharmacokinetic profiles that suggest accumulation will not occur and that recovery will be rapid. These drugs include the hindered phenol agent propofol and the short-acting narcotic alfentanil. The newer muscle relaxants atracurium and vecuronium complete the pharmacological picture. Infusion pumps are now available which can be programmed to deliver accurate doses of these agents in a relatively fail-safe manner, and programs are being written using the pharmacokinetic profiles of these drugs to determine doses required for any given patient. ${ }^{1,2}$

Total Intravenous Anaesthesia (TIVA) is a concept that arises naturally from these developments. It is the next step in the evolution of the concept of balanced anaesthesia which obviates the need for an inhalational agent while maintaining the anaesthetic state with infusions of shortacting intravenous drugs alone. For example, hypnosis is

Department of Anaesthesia, Mount Sinai Hospital, University of Toronto, Toronto, Ontario. induced with a loading dose of propofol, the pressor response to intubation attenuated with a loading dose of alfentanil, paralysis and tracheal intubation facilitated with vecuronium, and the anaesthetic state maintained with titratable infusions of propofol, alfentanil and vecuronium. The lungs may be ventilated with oxygen or an air/oxygen mixture to avoid all inhalational anaesthetic agents. At the termination of surgery all infusions are discontinued, residual muscle relaxation is reversed, and arousal occurs promptly, usually within ten minutes.

What, if any, advantages does TIVA have over the techniques with which we are all familiar? The elimination of nitrous oxide confers many theoretical and real benefits to patients. Risks attendant on its use include the limitation of inspired oxygen concentration, exacerbation of air embolus or pneumothorax, ${ }^{3}$ diffusion into closed body cavities such as the inner ear or emphysematous bullae, ${ }^{3}$ elevation of pulmonary vascular resistance and pulmonary artery pressure in predisposed patients, ${ }^{4}$ bone marrow suppression following prolonged administration, ${ }^{5}$ and elevation of intracranial pressure in patients with pre-existing intracranial hypertension. ${ }^{6}$ Chronic exposure to low levels of nitrous oxide has been questioned as an occupational hazard for OR personnel. ${ }^{7}$ The elimination of volatile agents may likewise have some advantages. None of the intravenous drugs has been shown to have organ toxicity while the volatile agents have been implicated in both hepatic and renal toxicity. The possibility of teratogenic, mutagenic or carcinogenic effects of trace concentrations of volatile agents becomes a non-issue. The necessity for accurately calibrated vaporizers is obviated, as is the use of mass spectrometry to monitor inspired and end-tidal anaesthetic concentrations. Finally, the proponents of TIVA suggest that the overall anaesthetic experience is more "pleasant"; a claim that will be extremely difficult to substantiate experimentally.

No technique, however, is without disadvantages, Whenever fixed doses of intravenous agents are used their pharmacokinetic and pharmacodynamic effects vary according to the patient's physiology. A given dose of an anaesthetic will affect a patient in haemorrhagic shock differently from a haemodynamically stable patient. The 
haemodynamic state may vary greatly during any surgical procedure, especially those in which large fluid shifts may occur. Unlike a volatile agent, once an intravenous drug is given it cannot be recovered. With volatile agents we can estimate their partial pressure in the blood by monitoring end-tidal concentrations; no equivalent real-time measures of intravenous drug blood concentrations exist. Should hidden blood loss occur, profound circulatory depression may occur due to deepening of anaesthesia. Also, since the anaesthetic state depends on the intravenous infusion of drugs, the technique would seem to require a second dedicated intravenous line.

Finally, and of paramount importance, is the problem of intraoperative awareness. Most of us are very familiar with techniques involving volatile agents; with modern calibrated vaporizers and the concept of MAC ingrained in us awareness is extremely rare when volatile agents are used. However, awareness under anaesthesia is a major threat with a total intravenous technique. If TIVA is to become successful this problem will have to be addressed. At present there is no adequate routine monitor to assure us that our patient is not conscious. We must rely on our clinical acumen and knowledge of the doses which usually prevent awareness. Prys-Roberts and his colleagues have made a first step in describing the minimal infusion rate for propofol which is necessary to prevent movement. ${ }^{8}$ Much work remains to be done before many of us will be confident that patients receiving TIVA are not aware.

There is no doubt that Total Intravenous Anaesthesia is a concept whose time has come. Many groups share great interest in the technique. In the future we will see many improvements as the concept is "fine tuned." It certainly will have a place in procedures such as airway endoscopies where venturi ventilation precludes the use of inhaled agents. Whether it will impact further into the practice of anaesthesia remains to be seen.

\section{Anesthésie intraveineuse}

La quête du parfait équilibre entre les diverses facettes de l'état anesthésique (l'hypnose, la diminution des réflexes végétatifs et le relâchement musculaire) sous tend l'usage actuel d'un combiné de divers médicaments aux effets spécifiques car il n'existe pas d'anesthésique utilisable seul en dose raisonnable et offrant un "large spectre" d'effet. Ainsi, pour restreindre la toxicité associée aux fortes doses, on combine des quantités modérées d'anesthésique inhalé, de barbiturique pour induire l'hypnose, de curare pour assurer le relâchement et de morphinique pour émousser les réflexes végétatifs.

Aux thiopental, morphine, mépéridine et d-tubocurarine utilisés depuis longtemps par voie intraveineuse, se sont ajoutés plus récemment le fentanyl et le pancuronium. Malheureusement tous ces médicaments ont tendance à l'accumulation et ceci est encore plus évident lorsque pour compenser l'absence de protoxyde d'azote, on en augmente les doses. Ainsi, à mesure que ces dernières se répètent, leur durée d'action s'allonge, prolongeant la récupération à la mesure de la durée de l'intervention. La cinétique particulière d'une nouvelle genération de produits laisse entrevoir une absence d'accumulation et une récupération rapide. Il s'agit du propofol (dérivé phénolique), de l'alfentanil (morphinique à action courte), et des curres atracurium et vécuronium. Il existe par ailleurs des pompes compactes, programmables de façon à assurer un dosage exact de ces médicaments. $\mathrm{Ce}$ dernier pourra être adapté à chaque patient grâce à des logiciels en développement intégrant les profils pharmacocinétiques des drogues. ${ }^{1,2}$

On en vient alors à entrevoir la possibilité d'une anesthésie exclusivement intraveineuse (AEI) basée sur de multiples perfusions de produits de courte durée. Ainsi, on induit l'hypnose avec un bolus de propofol alors qu'un bolus d'alfentanil atténue la réponse hémodynamique à l'intubation rendue facile par du vécuronium. Tandis que le patient ne respire qu'un mélange d'air et oxygène, on maintien l'anesthésie et le relâchement musculaire avec des perfusions variables de propofol, d'alfentanil et de vécuronium jusqu'à la fin de l'intervention. A l'arrêt des perfusions, on injecte les antidotes des curares et l'éveil survient rapidement, habituellement en deçà de dix minutes.

Quels seraient les avantages de l'AEI sur les méthodes plus conventionnelles? Tout d'abord, l'omission du protoxyde d'azote offre des avantages théoriques et pratiques parce que son usage limite la $\mathrm{FIO}_{2}$ et qu'il peut envenimer une embolie aérienne ou un pneumothorax. ${ }^{3}$ Le $\mathrm{N}_{2} \mathrm{O}$ diffuse aussi dans les compartiments gazeux fermés tel l'oreille moyenne et les bulles d'emphysème, ${ }^{3}$ il augmente les résistances vasculaires pulmonaires chez certains patients, ${ }^{4}$ déprime la mœelle osseuse en usage prolonge ${ }^{5}$ et exacerbe l'hypertension intracrânienne. ${ }^{6}$ ll pourrait même présenter un danger pour le personnel de salle d'opération exposé chroniquement à de faibles concentrations. ${ }^{7} \mathrm{~L}$ 'élimination des autres vapeurs anesthésiques pourrait aussi être bénéfique. Aucun des anesthésiques intraveineux ne semble toxique alors qu'on a souvent démontré la toxicité héhaptique et rénale des vapeurs anesthésiques. ${ }^{7}$ Finies aussi les inquiétudes quant aux effets tératogéniques, 
mutagéniques ou carcinogéniques des traces de vapeur dans l'environnement. On n'aurait plus besoin de vaporisateur calibré non plus que de spectromètre de masse pour mesurer la concentration d'anesthésique en fin d'expiration. Finalement, les promoteurs de l'AEI en soulignent le caractère plus "agréable" pour le patient, prétention toutefois difficile à démontrer scientifiquement.

Toute méthode comporte cependant des limites. Ainsi, si on utilise des doses fixes d'anesthésiques intraveineux, leurs propriétés pharmacocinétiques et pharmacodynamiques dépendront en partie de la physiologie du patient. La réponse du patient qui est en choc hémorragique différera de celle d'un autre dont l'hémodynamie est adéquate. L'équilibre hémodynamique peut aussi varier beaucoup pendant une intervention chirurgicale, surtout si elle s'accompagne de grandes translocations liquidiennes. Contrairement aux anesthésiques en inhalation, on ne peut récupérer ceux qu'on a injectés non plus qu'en monitorer les concentrations tissulaires. Si on sousestimait la perte sanguine, on pourrait alors voir s'approfondir le niveau d'anesthésie, entraînant avec lui un collapsus circulatoire. La technique d'AEI requière aussi une deuxième voie veineuse consacrée exclusivement aux perfusions d'anesthésiques.

Depuis que nous sommes familiers avec le concept de concentration alvéolaire minimale (MAC) et que nous disposons de vaporisateurs bien calibrés, le problème de l'éveil peropératoire ne se pose quasiment pas avec les anesthésiques en inhalation. Il en va tout autrement avec les anesthésiques intraveineux pour lesquels nous devons encore nous fier sur notre sens clinique et sur notre connaissance des doses qui préviennent habituellement l'éveil, à défaut d'un moniteur fiable du niveau de conscience. Prys-Roberts et ses collègues viennent de jeter un premier jalon en mesurant le taux de perfusion de propofol nécessaire à la prévention des mouvements. ${ }^{8}$ Toutefois il reste beaucoup de chemin à faire avant que la plupart d'entre nous soient convaincus que l'AEI peut garantir l'inconscience.

L'AEl arrive pourtant à point nommé. Plusieurs groupes s'y intéressent et arriveront sans doute à en raffiner la technique. Elle trouvera sans doute sa place lors des endoscopies des voies respiratoires où la ventilation par "Venturi" rend difficile l'usage de vapeurs anesthésiques. L'avenir nous dira toutefois si l'AEI aura un impact plus grand sur l'anesthésie de demain.

\section{References}

1 Ausens $M E$, Stanski DR, Hug CC. An evaluation of the accuracy of pharmacokinetic data for the computer assisted infusion of alfentanil. Br J Anaesth 1985; 57: 1217-25.

2 Schuttler J, Kloos S, Schwilden H, Stoeckel $H$. Total intravenous anacsthesia with propofol and alfentanil by computer-assisted infusion. Anaesthesia 1988; 43: (Suppl) 2-7.

3 Gold MI, Joseph SI. Bilateral tension pneumothorax following induction of anesthesia in two patients with chronic obstructive airway disease. Anesthesiology 1973; 38: 93-7.

4 Schulte-Sasse E, Hess W, Tarnow J. Pulmonary vascular responses to nitrous oxide in patients with normal and high pulmonary vascular resistance. Anesthesiology 1982; 57: 9-13.

$5 O^{\prime}$ Sullivan $H$, Jennings $F$, Ward $K, M c C a n n S$, Scott JM, Weir $D G$. Human bone marrow biochemical funtion and megaloblastic hematopoiesis after nitrous oxide anesthesia. Anesthesiology 1981; 55: 645-9.

6 Moss E, McDowall DG. ICP increases with 50 percent nitrous oxide in oxygen in severe head injuries during controlled ventilation. $\mathrm{Br} J$ Anaesth 1979; 51: 757-61.

7 Cohen EN, Brown BW, Wu ML et al. Occupational disease in dentistry and chronic exposure to trace anesthetic gases. J Am Dent Assoc 1980; 101: 21.

8 Prys-Roberts C. Sear JW. Adam HK. Pharmacokinetics of continuous infusions of althesin, minaxolone and $\mathrm{ICI}$ 35,868. Br J Anaesth 1981; 53: 115P. 